\title{
Desain Perangkat Dapur Untuk Tunanetra dengan Konsep Clean Design
}

\author{
Desi Putri Islamy dan Primaditya \\ Departemen Desain Produk, Fakultas Arsitektur Desain Dan Perencanaan, \\ Institut Teknologi Sepuluh Nopember (ITS) \\ e-mail:primadity@prodes.its.ac.id
}

\begin{abstract}
Abstrak-Tunanetra dituntut untuk menggunakan produk yang sama dengan produk yang digunakan oleh orang dengan penglihatan normal dalam kesehariannya, salah satunya pada aktivitas di dapur. Aktivitas di dapur ini rawan kecelakaan, terlebih pada aktivitas yang berhubungan dengan air panas. Maka pelatihan memasak dan pembelajaran activity daily living yang gencar diadakan oleh komunitas dan lembaga mendapatkan respon positif oleh tunanetra di Surabaya. Analisis diawali dengan interview pada dua lembaga tunanetra, dua organisasi tunanetra, serta dua orang tunanetra di Surabaya. Hasil dari wawancara dan shadowing yang telah dilakukan akan menghasilkan desain perangkat dapur dengan konsep clean design guna memudahkan tunanetra dalam mengoperasionalkan perangkat, serta hasil desain perangkat harus yang sesuai dengan kebutuhan dan dapat menunjang tunanetra untuk dapat berkontribusi dalam kegiatan ekonomi di masyarakat.
\end{abstract}

Kata Kunci-Tunanetra, Disabilitas, Perangkat Dapur, Clean Design, Kognitif (key words)

\section{PENDAHULUAN}

$\mathrm{M}$ EMASAK merupakan aktivitas yang dilakukan secara rutin guna memenuhi kebutuhan pangan dalam seharihari, tidak terkecuali untuk orang dengan kebutuhan khusus seperti visual impairment atau umum diketahui sebagai tunanetra. Tunanetra yang mengalami kebutaan sejak lahir maupun karena kondisi tertentu merupakan gangguan penglihatan yang tidak dapat diatasi dengan menggunakan kacamata atau lensa kontak [1], sehingga dengan kondisi mata yang tidak berfungsi seperti penglihatan orang normal akan sangat berpengaruh pada aktivitas keseharian, salah satunya aktivitas di dapur.

Maka beberapa tahun terakhir sejak tahun 2012 mulai diagendakan pelatihan tata boga untuk tunanetra. Diantaranya adalah ITMI (Ikatan Tuna Netra Muslim Indonesia) mengajukan pelatihan tataboga ke Rumah Zakat di Depok [1]. Kemudian DPD Pertuni Jawa Timur pada tanggal 26-28 Oktober 2012 yang difasilitasi BKKKS Provinsi Jawa Timur di ruang pelatihan BKKKS mengadakan kegiatan pelatihan tata boga untuk meningkatkan kesejahteraan tunanetra di Surabaya. Lalu pada tahun 2014 Dinsos Kota Surabaya dengan TCI (Tastar Culinary Institute) mengadakan pelatihan kuliner yang merupakan bagian dari program kesejahteraan bagi PMKS Kota Surabaya Tahun 2014.

Namun dengan beberapa progam untuk meningkatkan produktifitas disabilitas, dalam pernyataan Kamar Dagang Dan Industri (KADIN) Surabaya yang merupakan mitra dari Pemerintah Kota Surabaya [2], ternyata masih terdapat rendahnya kepekaan dan pemahaman masyarakat terhadap kebutuhan khusus penyandang disabilitas. Latar belakang beberapa sebab yang mengakibatkan gangguan penglihatan, di Indonesia sendiri tunanetra menempati peringkat ke empat dari tujuh jenis penderita disabilitas, seperti yang dijelaskan oleh Badan Pusat Statistik Jawa Timur [2]. Hal tersebut membuat penyandang disabilitas kesulitan untuk berpartisipasi dalam kehidupan sosial dan ekonomi. Tunanetra harus dilayani dan tidak mandiri masih menjadi stereotip masyarakat, sejatinya tunanetra pun harus melalui keseharian dengan aktivitas yang sama seperti orang dengan penglihatan normal dalam kesehariannya [3]. Tunanetra juga harus bekerja untuk memenuhi kebutuhan sehari-hari termasuk aktivitas didapur yang merupakan salah satu activity daily living (ADL) untuk memenuhi kebutuhan pangan.

\section{II.URAIAN PENELITIAN}

Metode pada penelitian ini adalah wawancara dan shadowing dimana data yang didapat relevan dengan keadaan sebenarnya pada pengguna. Shadowing dilakukan dengan memperhatikan dan mendokumentasikan aktivitas pengguna dalam kesehariannya. Data yang didapat dari proses shadowing diolah hingga menghasilkan desain perangkat dapur yang sesuai berdasarkan pengalaman pengguna.

Kemudian melakukan analisis konfigurasi berdasarkan komponen yang akan digunakan dalam desain dengan menerapkan konsep clean design yang dicapai dengan indikator kognitif dan unity.

Hasil konfigurasi terpilih dijadikan acuan dalam desain bentuk yang diaplikasikan dalam pembuatan beberapa model menggunakan clay sebagai analisis ergonomi. Model yang dihasilkan kemudian dilakukan usability test kepada pengguna untuk mengetahui pendapat pengguna. Dalam proses ini digunakan metode partisipatory dimana pengguna turut serta memberikan saran dan kritik untuk desain yang dihasilkan [4].

Kemudian mengolah desain menggunakan software $3 D$ sebagai visualisasi dari data yang dihasilkan pada model terpilih. Dari hasil visualisasi kemudian dilakukan proses pengembangan model.

\section{HASIL DAN PEMBAHASAN}

\section{A. Analisis Aktifitas}

Wawancara dan shadowing yang telah dilakukan menghasilkan kesimpulan bahwa aktivitas yang setiap hari dilakukan secara berkelanjutan adalah membuat air minum. Pada aktivitas ini pengguna mengalami beberapa kesulitan 
diantaranya dalam mengetahui batas air ketika menuang air minum, air tumpah ketika menuang, jari terkena percikan air panas ketika berada disekitar bibir gelas, serta kesan tidak higenis ketika ibu jari menyentuh air untuk mengetahui batas air yang berada di dalam gelas yang dapat dilihat pada Gambar 1.

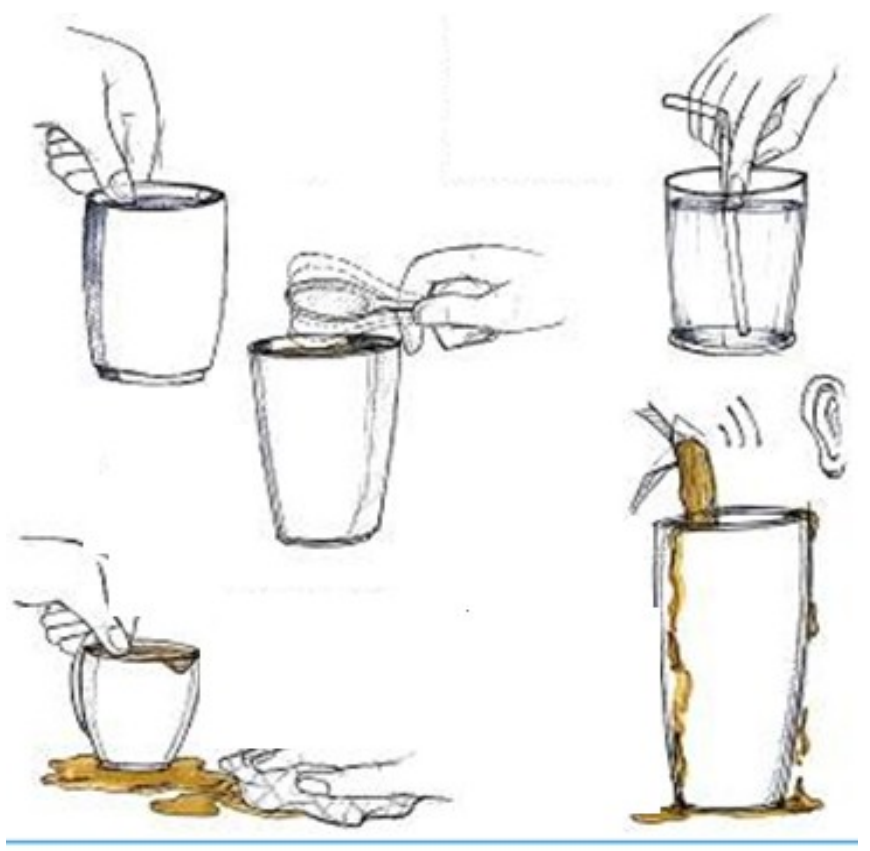

Gambar 1. Ilustrasi aktivitas mengetahui batas air ketika menuang air minum.

\section{B. Analisis Konfigurasi}

Data dari hasil shadowing kemudian diolah hingga menemukan desain dan produk yang sesuai dengan kebutuhan, dalam hal ini indikator batas air yang mampu dan mudah digunakan oleh pengguna adalah dengan penggunaan komponen elektronik sehingga relevan dengan keseharian pengguna yang tidak lepas dari penggunaan teknologi.

Komponen utama yang digunakan adalah arduino pro mini dan didukung beberapa komponen lainnya, dimana akan dihasilkan suara sebagai penanda air telah menyentuh batas tertentu. Data dari komponen yang telah dipilih diolah kembali hingga mendapatkan konfigurasi yang sesuai.

Konfigurasi komponen alternatif pertama pada Gambar 2 memperlihatkan antar komponen bertumpuk pada satu garis. Pada bagian bawah terdapat arduino pro mini, pada bagian atas arduino terdapat circuit cas beserta baterai lipo mini, sedangkan pada bagian bawah arduino terdapat tombol pengatur, dan pada sisi paling atas merupakan mini speaker.

Pada alternatif kedua posisi antar komponen sejajar. Urutan posisi komponen dimulai dari posisi teratas adalah mini speaker, aduino, circuit cas, baterai lipo mini, serta tombol pengatur pada sisi bawah.

Sedangkan pada alternatif ketiga merupakan kombinasi dari alternatif pertama dan kedua. Posisi arduino terletak pada sisi belakang, dengan circuit cas dan baterai lipo diatasnya, pada bagian teratas terdapat mini speaker, sedangkan untuk posisi tombol pengatur berada pada sisi kanan produk.

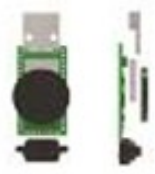

1
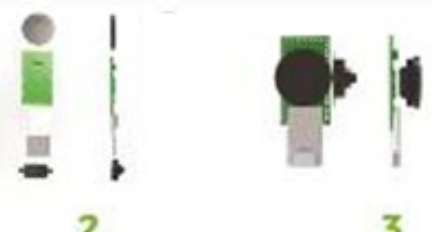

2
Gambar 2. Analisis konfigurasi.

Berdasarkan pertimbangan dari kelebihan dan kekurangan tiap alternatif, ditemukan konfigurasi yang dirasa sesuai terhadap kebutuhan. Alternatif pertama mendekati desain sesuai kebutuhan, dengan bentuk yang dihasilkan tidak terlalu tebal dan tidak terlalu panjang. Namun posisi cas lebih baik terletak pada sisi bawah produk seperti pada alternatif 3 sehingga sangat jauh dari resiko terkena percikan ketika menuang air. Maka pada desain indikator batas air menggunakan konfigurasi alternatif pertama seperti pada gambar dengan mengubah posisi cas pada bagian bawah serta pemilihan alternatif kedua untuk kebutuhan desain yang lebih ramping.

\section{C.Analisis Ergonomi}

Analisis dilakukan dengan eksplorasi bentuk berdasarkan konfigurasi terpilih, berikut merupakan tiga ekplorasi indikator batas air beserta hasil penilaian dari pengguna dari segi desain. Tabel 1 merupakan hasil eksplorasi dari bentuk perangkat dapur dengan peletakan komponen sesuai konfigurasi terpilih. Dimana kognitif yang merupakan salah satu indikaor untuk mencapai konsep clean design, memiliki arti mudah dipahami. Kognitif dalam konteks ini ditemui pada konfigurasi dan desain cover. Sehingga dari eksplorasi yang dilakukan ditemui desain yang sesuai dengan konsep clean design.

Tabel 1.

Eksplorasi Desain Bentuk

\begin{tabular}{|c|c|c|}
\hline No. & Eksplorasi & Keterangan \\
\hline 1. & & $\begin{array}{l}\text { Bentuk pada sisi atas dan bawah } \\
\text { datar, serta terdapat grip pada sisi } \\
\text { kanan dan kiri yang tidak terlalu } \\
\text { tebal. }\end{array}$ \\
\hline 2. & & $\begin{array}{l}\text { Bentuk pada sisi atas dan bawah } \\
\text { datar dengan sedikit lengkungan, } \\
\text { serta grip yang lebih besar dan tebal. }\end{array}$ \\
\hline 3. & & $\begin{array}{l}\text { Bentuk pada sisi aas dan bawah } \\
\text { terdapat lengkungan, serta ukuran } \\
\text { grip pada sisi samping berukuran } \\
\text { kecil. }\end{array}$ \\
\hline
\end{tabular}


Kemudian untuk menentukan desain yang sesuai konsep clean design didapatkan kesimpulan dari penilaian sebagai berikut :

a. Peringkat penilaian diferensiasi

$$
3 \text { = Sangat Baik, } 2 \text { = Baik, } 1=\text { Kurang }
$$

b. Parameter Clean Design

Dicapai oleh indikator unity dan cognitive berdasarkan konfigurasi, bentuk secara keseluruhan, serta detail pada bagian tertentu yang ada pada interface dengan pemberian skor :

$1=<50 \%$ dari interface terlihat menyatu

$2=<75 \%$ dari interface terlihat menyatu

$3=>80 \%$ dari interface terlihat menyatu

Tabel 2.

Hasil Penilaian Eksplorasi

\begin{tabular}{lccc}
\hline \multicolumn{4}{c}{ Hasil Penilaian Eksplorasi } \\
$\begin{array}{l}\text { Eksplorasi } \\
\text { Responden }\end{array}$ & 1 & 2 & 3 \\
\hline Andega & 1 & 2 & 1 \\
Hamasah & 1 & 2 & 2 \\
Vebri & 2 & 2 & 1 \\
One & 1 & 1 & 3 \\
Rizal & 3 & 3 & 1 \\
Danny & 2 & 1 & 3 \\
Ipung & 1 & 1 & 2 \\
Prana & 1 & 1 & 2 \\
Rata - rata & 12 & 13 & 15 \\
\hline \hline
\end{tabular}

Kesimpulan dari hasil penilaian pada desain bentuk indikator batas air secara keseluruhan, bentuk dari desain mendekati eksplorasi desain nomor 4. Bentuk pada bagian atas dan bawah terdapat lengkungan, serta ukuran grip pada sisi samping yang berukuran kecil.

Kemudian dilakukan eksplorasi bentuk konduktor, yaitu merupakan penghantar yang mendukung sensor bekerja hingga dapat mengeluarkan suara. Pada indikator batas air jumlah konduktor menentukan batasan output yang diinginkan. Sistem kerja konduktor dengan membaca liquid yang menyentuh konduktor pertama dan konduktor kedua yang memiliki perbedaan posisi atau ketinggian.

Berdasarkan hasil eksplorasi yang dilakukan pada Tabel 3 maka bentuk konduktor yang sesuai terlihat pada Gambar 5, ujung bagian bawah konduktor berbentuk lengkungan untuk memudahkan memposisikan konduktor pada berbagai gelas dengan ketebalan berbeda. Konduktor pertama dan kedua berada pada jarak $5 \mathrm{~mm}$ guna menghindari konduktor bersentuhan yang akan mengaktifkan perangkat secara otomatis. Ketinggian pada konduktor pertama $3 \mathrm{~mm}$ lebih tinggi agar sistem dapat terbaca.

\section{D.3D Modeling}

Hasil dari konfigurasi terpilih dilakukan proses penerjemahan desain hingga proses visualisai desain menggunakan software $3 \mathrm{~d}$ guna mudah memahami bentuk sebelum proses prototipe. Software yang digunakan dalam proses ini adalah Autodesk fusion 360.

Indikator Batas Air terdapat dua ukuran, pada gambar 3 dan gambar 4 adalah indikator air dengan ukuran kecil yang dapat digunakan pada gelas berukuran kecil, seperti pada gelas untuk membuat kopi atau teh. Konduktor berukuran pendek berfungsi untuk kebutuhan menuang air dengan ukuran penuh.

Tabel 3.

Eksplorasi Bentuk Konduktor

\begin{tabular}{lll}
\hline \hline No. & Eksplorasi & Keterangan \\
\hline
\end{tabular}
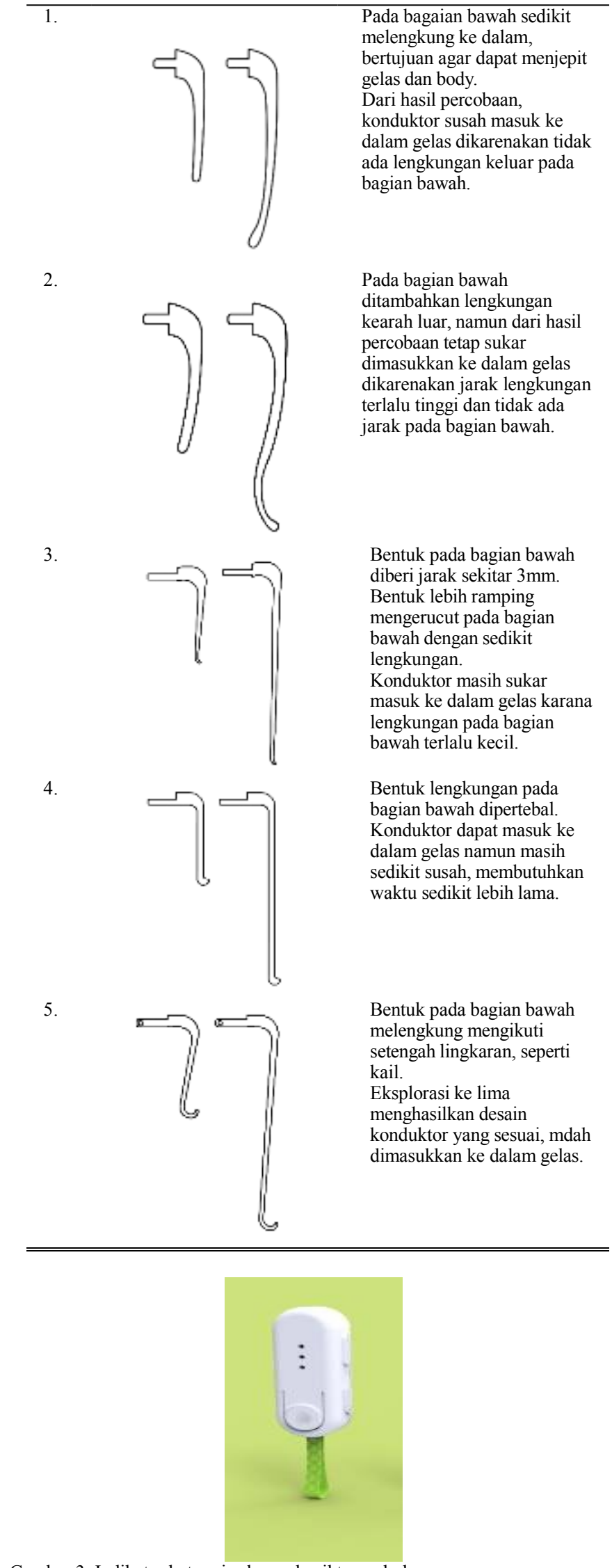

Gambar 3. Indikator batas air ukuran kecil tampak depan. 


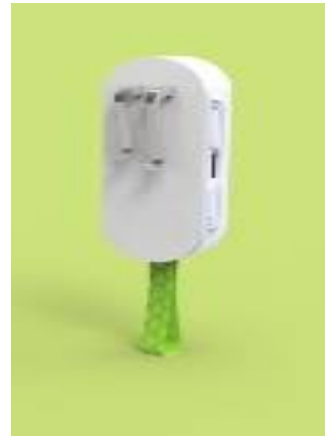

Gambar 4. Indikator batas air ukuran kecil tampak belakang.

Sedangkan pada Gambar 5 merupakan indikator batas air berukuran besar yang dapat digunakan pada gelas ukuran lebih panjang, konduktor pada bagian belakang lebih panjang berfungsi untuk kebutuhan menuang air dengan ukuran separuh gelas atau tidak penuh. Perbedaan indikator batas air kecil dan panjang terdapat pada ukuran yang didapatkan berdasarkan konfigurasi, sedangkan pada desain bentuk keseluruhan didapatkan dari hasil eksplorasi bentuk.

Gambar 5. Indikator batas air ukuran besar tampak depan.

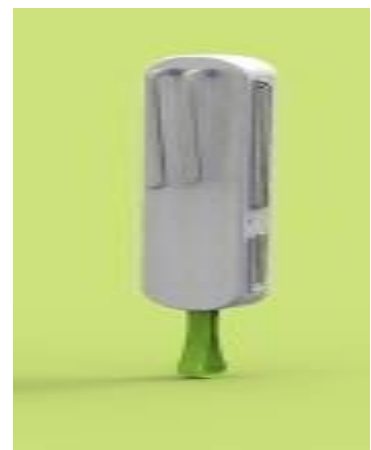

Gambar 5. Indikator batas air ukuran besar tampak belakang.

Hasil desain yang telah melalui proses eksplorasi sebelumnya sesuai dengan kebutuhan, desain yang sederhana tidak memiliki banyak ornamen dengan konfigurasi yang sesuai menghasilkan clean design. Penambahan tali pada produk digunakan sebagai opsional untuk memudahkan pengguna dalam membawa produk secara mobile serta memudahkan dalam penyimpanan dengan digantung.

Hasil akhir desain juga mudah diketahui penggunaan produk dengan memposisikan produk secara vertical sejajar dan terpasang pada bibir gelas yang terlihat pada gambar 6 , yaitu posisi indikator batas air kecil pada gelas untuk membuat kopi yang berukuran kecil.

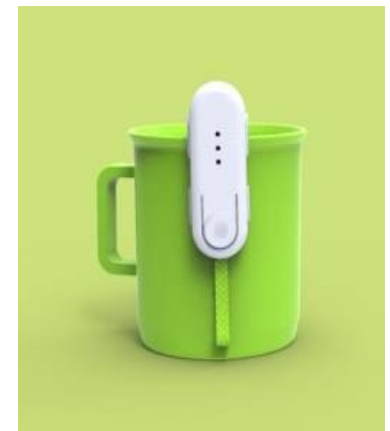

Gambar 6. Indikator batas air ukuran kecil pada gelas berukuran pendek.

Sedangkan pada Gambar 7 merupakan indikator batas air besar yang diposisikan pada gelas berukuran lebih panjang. Ukuran indikator batas air besar yang sesuai dengan ukuran gelas tertentu yang lebih panjang menghasilkan kesan unity dan clean design.

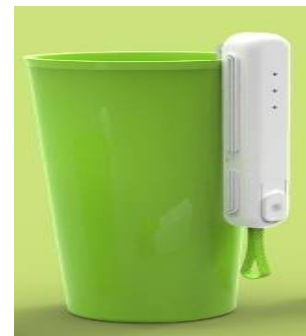

Gambar 7. Indikator batas air ukuran besar pada gelas berukuran pendek.

\section{E. Usability Test}

Dalam tahapan ini prototip harus sudah siap untuk di uji coba oleh pengguna karena pengguna secara langsung akan mencoba dan memberikan tanggapan dari produk yang telah dihasilkan.

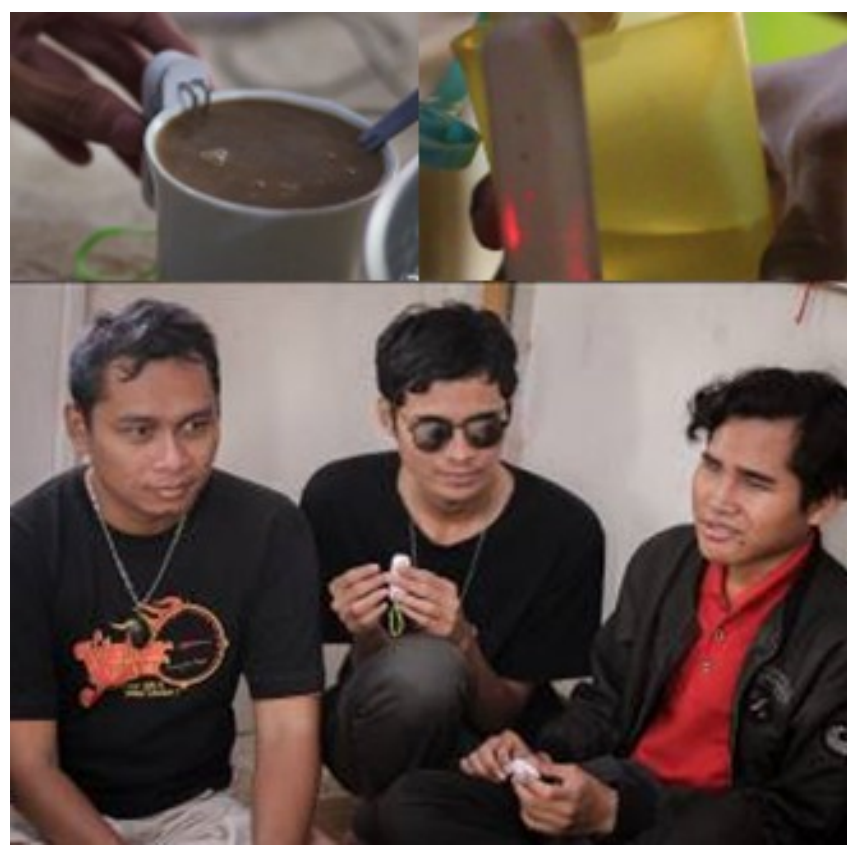

Gambar 8. Dokumentasi usability test.

Pada Gambar 8 usability test dilakukan dengan anggota Komunitas Mata Hati. Danny, Ipung, dan Prana merupakan anggota aktif komunitas yang juga merupakan mahasiswa di 
salah satu Universitas di Surabaya. Pada proses usability test dapat diketahui interaksi pengguna terhadap produk [5], dimulai dari mencari tahu tekstur, bentuk, bagian produk, hingga menggunakan produk. Pengguna mulai menggunakan produk dengan menyusuri tali yang terdapat pada sisi bawah produk, kemudian mengarah pada sisi depan produk yaitu pada sisi yang terdapat lengkungan hingga ditemui trigger berupa tombol dengan desain lebih timbul dan cekungan pada bagian tengah yang menandakan berfungsi dengan ditekan. Perangkat dalam keadaan berfungsi jika trigger berupa tombol ketika ditekan akan menghasilkan feedback berupa suara "klik". Begitu pula dalam mematikan produk dengan menekan tombol yang sama hingga menghasilkan feedback suara "klik".

Grip yang berada pada sisi kanan dan kiri perangkat sebagai penanda dalam memposisikan produk ketika digunakan yaitu berdiri sejajar dengan gelas. Pada bagian belakang produk ditandai dengan bentuk yang datar disertai adanya konduktor dengan bentuk yang sesuai dan mudah dalam memposisikan perangkat.

Perangkat dalam keadaan berfungsi jika setelah keadaan aktif dan digunakan, akan ada feedback berupa output suara yang menandakan air telah meyentuh indikator.

\section{KESIMPULAN}

Dari hasil penelitian yang dilakukan dapat disimpulkan sebagai berikut:

1. Pada indikator batas air grip yang berada pada sisi kanan dan kiri perangkat sangat berpengaruh dan mudah dipahami oleh pengguna sebagai penanda dalam memposisikan produk ketika digunakan yaitu berdiri sejajar dengan gelas.

2. Desain dari tombol yang menyatu dengan casing menghasilkan clean design. Tombol lebih tebal dibandingkan interface sekitarnya sebagai penanda terdapat bagian yang memiliki fungsi, kemudian pada bagian tengah tombol terdapat sedikit cekungan sebagai penanda bahwa tombol dioperasionalkan dengan cara ditekan.
3. Memaksimalkan penggunaan arduino dengan menambah batas air yang dapat dicapai, dilakukan dengan menambahkan jumlah konduktor pada sisi bagian belakang sesuai kebutuhan dengan tetap berpegang pada ketentuan jika air yang terbaca oleh sistem adalah yang menyentuh ujung konduktor pertama dan ujung konduktor kedua.

4. Desain akhir dari indikator batas air dapat mendukung pengguna untuk beraktivitas dengan aman dan nyaman. Tidak hanya terbatas pada aktivitas dirumah, dengan adanya perangkat dapur untuk tunantra pengguna dapat turut serta berkontribusi pada perekonomian dimasyarakat tanpa dipandang berbeda serta mendapatkan kepercayaan lebih.

\section{UCAPAN TERIMA KASIH}

Penulis mengucapkan terimakasih kepada mitra yang telah terlibat sehingga penulis dapat memiliki data yang relevan dan akurat, yaitu kepada Lembaga Pemberdayaan Tunanetra Jawa Timur, Yayasan Penyandang Anak Buta Surabaya, Komunitas Mata Hati Surabaya, serta Alumni Panti Rehabilitasi Cacat Netra.

\section{DAFTAR PUSTAKA}

[1] D. Hallahan, J. Kauffman, and P. C. Pullen, Introduction to Special education. 2009.

[2] S. Huda and J. Nurcahyo, "Upaya food \& baverage product dalam meningkatkan kualitas makanan di hotel grand aston yogyakarta," $J$. Khasanah Ilmu, vol. 6, no. 1, 2015.

[3] Z. Qodir, "Jatim memiliki 243.441 penyandang disabilitas," kadinsurabaya.or.id, 2017. $\quad$ [Online]. $\quad$ Available: http://kadinsurabaya.or.id/read/jatim-memiliki-243-441-penyandangdisabilitas.

[4] [BPS] Badan Pusat Statistika, "Persentase penyandang disabilitas menurut jenis gangguan yang dialami, tahun 2012," 2012. [Online]. Available:

https://jatim.bps.go.id/statictable/2015/03/05/233/persentasepenyandang-disabilitas-menurut-jenis-gangguan-yang-dialami-tahun2012.html.

[5] A. D. Sucianti, S. Handariatul, and S. I. Ayuning Khairunnisa, "Peran indera peraba dan indera lainnya dalam desain rumah hunian untuk tunanetra," in Prosiding Antropologi Sosiologi Desain II, 2014. 